\title{
Special aspects of the development of black currant bushes depending on weediness level in the Ukrainian polissia
}

\author{
A.V. Bakalova ${ }^{1}$, N.V. Hrytsiuk ${ }^{1}$, S.H. Stoliar ${ }^{1}$, N.M. Tkalenko ${ }^{2}$ \\ ${ }^{1}$ Zhytomyr National Agroecological University, \\ 7, Staryi Blvd, Zhytomyr, 10008, Ukraine \\ ${ }^{2}$ Institute for Plant Protection of NAAS, Ukraine
}

Corresponding author E-mail: bakalova1970@ukr.net

Received: 07.07.2020. Accepted: 07.08.2020

\begin{abstract}
The article provides the results of scientific study of different weediness levels in the currant agrocoenosis of Ukrainian Polissia. The species composition of weeds has been analyzed; it has been found that it is typical for the area. Twelve weed species were found during the study; they included annual (89.8\%) and perennial ones (10.2\%). A number of species were prevalent among the perennial weeds, namely common dandelion (Taraxacum officinale Wigg.) $-2.5 \mathrm{pcs} / \mathrm{m}^{2}$, field milk thistle (Sonchus arvensis L.) $-2.8 \mathrm{pcs} / \mathrm{m}^{2}$, couch grass (Elytrigia repens L.) $-8.8 \mathrm{pcs} / \mathrm{m}^{2}$, and field sorrel (Rumex acetostella L.) $-3.2 \mathrm{pcs} / \mathrm{m}^{2}$. The most common annual species of weeds were lamb's quarters (Chenopodium album L.) $-44.2 \mathrm{pcs} / \mathrm{m}^{2}$, shepherd's purse (Capsella bursa-pastoris L.) $-36.3 \mathrm{pcs} / \mathrm{m}^{2}$, smooth meadow grass (Poa annua L.) - $25.1 \mathrm{pcs} / \mathrm{m}^{2}$, and Amaranthus retroflexus (Amaranthus retroflexus L.) - $19.6 \mathrm{pcs} / \mathrm{m}^{2}$. Throughout the study period, the least common weeds in black currant plantations were chickweed (Stellaria media L.) $-14.8 \mathrm{pcs} / \mathrm{m}^{2}$, annual nettle (Urtica urens L.) - $1.6 \mathrm{pcs} / \mathrm{m}^{2}$, quickweed (Galinsoga parviflora Cav.) $-9.1 \mathrm{pcs} / \mathrm{m}^{2}$, and field pansy (Viola arvensis Murr.) $-2.6 \mathrm{pcs} / \mathrm{m}^{2}$. It has been proven that depending on the weediness level (8-9 points) the area of black currant leaves from a bush decreases by $1.9 \mathrm{~m}^{2}$, while the chlorophyll content in the leaves is by $20.8 \mathrm{mg} / 100 \mathrm{~g}$ less. On the contrary, the dry matter content in leaves increases from 29 to $61 \%$. Significant negative effect of weeds on the activity of black currant occupies one of the leading places and leads to a decrease in plant tolerance against sucking pests and diseases. Thus, under high and very high weediness level (8-9 points) the development of anthracnose (Gioesporium ribis Mont.) was 32-48\%, powdery mildew (Sphaerotheca mors Uvae.) and septoria blight (Mycosphaerella ribis Lind.) 16 and 15\% respectively. It has been proven that a high weediness level in black currant plantations reduces the yield of berries by $56 \%$.
\end{abstract}

Keywords: Black currant; Weeds; Yielding capacity; Weediness level; Phytophagous insects; Diseases

\section{Introduction}

Black currant is one of the most valuable vitamin berry crops for medicine and food industry (Postolenko, 2016). In Ukraine, black currant is the leading berry crop; it occupies more than $20 \%$ of all berry fields (Dobrucka et al., 2016). Black currant has a special place among berry crops due to its early maturity, high productivity, winter hardiness, the possibility of mechanical harvesting of berries and suitability for almost all types of technological processing (Bakalova et al., 2020). However, many years of cultivation contribute to the spread of diseases, pests and weeds; the decline of berry yield capacity can reach $30 \%$ or more (Marsol-Vall et al., 2019). One of the reasons for the low realization of productivity potential is primarily the weediness of industrial currant plantations (Aliev et al., 2018). The high level of weediness complicates mechanized harvesting, reduces the quality and marketable condition of products (Kjaer et al., 2019; Rantala et al., 2019). Literature sources do not have enough data on the level of weediness of black currant agrocoenoses in the Ukrainian Polissia. Therefore, it is relevant to conduct a thorough study of the influence of various weediness levels on black currant plantations and to obtain high yields of berries.

The purpose of the study was to examine the species composition of weeds and investigate the influence of the weediness level on the main components of black currant agrocoenosis in the Ukrainian Polissia.

\section{Materials and Methods}

Field studies were conducted during 2017-2019 at the experimental field of Zhytomyr National Agroecological University. The soil of the experimental plots is sod-podzolic; it is characterized by the following agrochemical parameters: the humus content ranged from 1.7 to $2.0 \%$; easily hydrolyzed nitrogen compounds $68-117 \mathrm{mg} / \mathrm{kg}$, high content of mobile phosphorus $145-180 \mathrm{mg} / \mathrm{kg}$, average exchangeable potassium content $87-110 \mathrm{mg} / \mathrm{kg}$, hydrolytic acidity of soil $2.28-2.90 \mathrm{mg}-\mathrm{eq} / 100 \mathrm{~g}$ and pH of the salt extract $5.5-6.2$. The experiments were based on the methodology of B. A. Dospekhov (1985). In each variant, there were 60 bushes with five replications, 15 bushes in each. Agrestal vegetation was counted at the experimental plots in black currant plantations in spring after intensive sprouting. The calculation was based on the methodology of A. I. Maltsev and was carried out using ocular estimate method and quantitative-weighing method (Maltceva, 1936). A European 9-point scale was used to assess weediness (Table 1). The species composition of weeds was determined in two replicates of the experiment using atlases and reference books (Veselovskyi et al., 1988; Fisyunov, 1984). 
Table 1. Scale used to determine weediness level in black currant plantations.

\begin{tabular}{|c|c|c|c|c|}
\hline $\begin{array}{l}\text { Weediness } \\
\text { points } \\
1 \\
2-3 \\
4-5\end{array}$ & $\begin{array}{l}\text { Weediness } \\
\text { level } \\
\text { very low } \\
\text { low } \\
\text { medium }\end{array}$ & $\begin{array}{l}\text { Number of } \\
\text { weeds, pcs } / \mathbf{m}^{2} \\
0.1-3 \\
6-15 \\
16-50\end{array}$ & $\begin{array}{l}\text { Weight of } \\
\text { weeds, kg } \\
0.1 \\
0.7 \\
1.2\end{array}$ & $\begin{array}{l}\text { Ocular estimate } \\
\text { method } \\
\text { almost no weeds } \\
\text { very few weeds } \\
\text { few weeds }\end{array}$ \\
\hline $6-7$ & high & $51-100$ & 2.2 & $\begin{array}{l}\text { a lot of weeds, but less than } \\
\text { cultivated plants }\end{array}$ \\
\hline $8-9$ & very high & more than 100 & 2.4 & $\begin{array}{l}\text { more weeds than cultivated } \\
\text { plants; and they overgrow } \\
\text { cultivated plants }\end{array}$ \\
\hline
\end{tabular}

Mathematical processing of experimental data was carried out according to conventional methods using the statistical program Statistika V 5.5 and the data analysis package of the Excel spreadsheet.

\section{Results}

The weediness level of black currant plantations was studied; as a result, it has been found that the species composition of weeds is diverse and typical for the investigated area. During the study period, 12 species of weeds $\left(170.6 \mathrm{pcs} / \mathrm{m}^{2}\right)$ were found in the plantations, among them 8 annual species $\left(153.3 \mathrm{pcs} / \mathrm{m}^{2}\right.$, or $\left.89.8 \%\right)$ and 4 perennial species $\left(17.3 \mathrm{pcs} / \mathrm{m}^{2}\right.$, or $\left.10.2 \%\right)$. The dominant species of annual weeds were Chenopodium album L. (44.2 pcs $\left./ \mathrm{m}^{2}, 26 \%\right)$, Capsella bursa-pastoris L. (36.3 pcs $\left./ \mathrm{m}^{2}, 21 \%\right)$, Poa annua L. $\left(25.1 \mathrm{pcs} / \mathrm{m}^{2}, 15 \%\right)$, and Amaranthus retroflexus L. $\left(19.6 \mathrm{pcs} / \mathrm{m}^{2}, 11 \%\right)$. Less common weeds in black currant plantations were Stellaria media L. (14.8 pcs $\left./ \mathrm{m}^{2}, 9 \%\right)$, Urtica urens L. $\left(1.6 \mathrm{pcs} / \mathrm{m}^{2}, 1 \%\right)$, Galinsoga parviflora Cav. $\left(9.1 \mathrm{pcs} / \mathrm{m}^{2}, 5 \%\right)$, and Viola arvensis Murr. (2.6 pcs $\left./ \mathrm{m}^{2}, 1 \%\right)$. The perennial species included Taraxacum officinale Wigg. $\left(2.5 \mathrm{pcs} / \mathrm{m}^{2}, 2 \%\right)$, Sonchus arvensis L. (2.8 pcs $/ \mathrm{m}^{2}$, $2 \%)$, Elytrigia repens L. (8.8 pcs $\left./ \mathrm{m}^{2}, 5 \%\right)$, and Rumex acetostella L . (3.2 pcs $\left./ \mathrm{m}^{2}, 2 \%\right)$ (Figure 1 ).

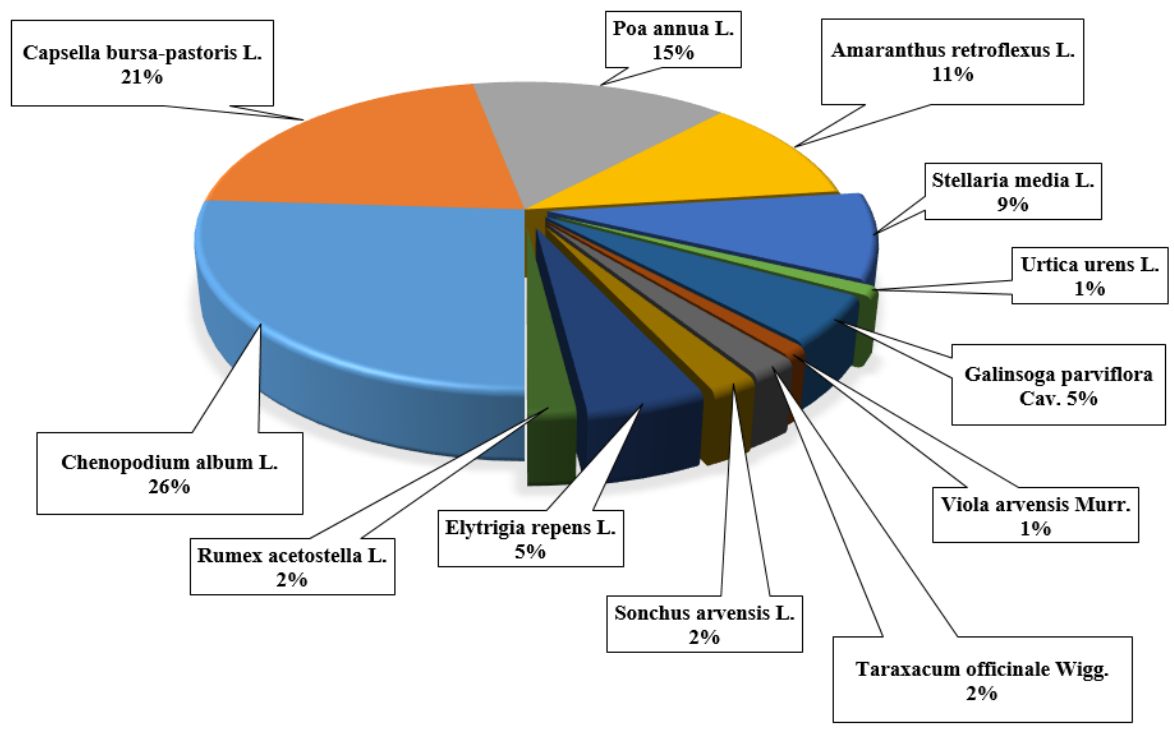

Figure 1. Species composition of weeds in black currant plantations, 2017-2019.

It has been found that depending on the different weediness level of black currant plantations, the growth and development of plants changes significantly (Table 2 ).

Table 2. Influence of different weediness levels on growth and development of black currant, 2017-2019.

\begin{tabular}{ccccccc}
\hline Weediness & $\begin{array}{c}\text { Weight of } \\
\text { black currant } \\
\text { leaves from } \\
\text { a bush, } \mathbf{~ k g}\end{array}$ & $\begin{array}{c}\text { Area of } \\
\text { black } \\
\text { currant } \\
\text { leaves from } \\
\text { level }\end{array}$ & $\begin{array}{c}\text { Chlorophyll } \\
\text { bush, } \mathbf{~ m}^{\mathbf{2}} \\
\text { content in } \\
\text { black currant } \\
\text { leaves, } \\
\text { mg/100g }\end{array}$ & $\begin{array}{c}\text { Net } \\
\text { photosynthetic } \\
\text { yield, } \mathbf{g} / \mathbf{m}^{2}\end{array}$ & $\begin{array}{c}\text { Dry matter } \\
\text { content in } \\
\text { black currant } \\
\text { leaves,\% }\end{array}$ \\
1 & very low & 1.0 & 3.1 & 59.1 & 3.9 & 29 \\
$2-3$ & low & 0.8 & 2.8 & 52.6 & 3.1 & 37 \\
$4-5$ & medium & 0.6 & 2.4 & 47.3 & 2.6 & 41 \\
$6-7$ & high & 0.4 & 1.6 & 42.6 & 1.8 & 58 \\
$8-9$ & very high & 0.3 & 1.2 & 38.3 & 1.6 & 61 \\
\hline
\end{tabular}

Depending on the weediness level, the weight of black currant leaves from a bush decreased by $0.7 \mathrm{~kg}$, the area of currant leaves from a bush by $1.9 \mathrm{~m}^{2}$, the chlorophyll content in the leaves by $20.8 \mathrm{mg} / 100 \mathrm{~g}$ compared to a very low weediness level (1 point). The dry matter content in currant leaves was $29-61 \%$ and, on the contrary, increased by $32 \%$ with a very high weediness level.

Weeds are a source of pests and diseases. Violation of biochemical processes in plants led to a decrease in the tolerance of currant to pests and diseases (Table 3). 
Table 3. Biological features of the development of sucking pests and diseases depending on the weediness level in black currant plantations, 2017-2019.

\begin{tabular}{|c|c|c|c|c|c|c|c|}
\hline \multicolumn{2}{|c|}{ Weediness } & \multicolumn{3}{|c|}{$\begin{array}{c}\text { Density of phytophagous insects } \\
\text { per unit } \\
\text { Tetranychu }\end{array}$} & \multicolumn{3}{|c|}{$\begin{array}{c}\text { Degree of } \\
\text { infestation, } \%\end{array}$} \\
\hline $\begin{array}{l}\text { poin } \\
\text { ts }\end{array}$ & $\begin{array}{c}\text { weediness } \\
\text { level }\end{array}$ & $\begin{array}{l}\text { Hyperomyzus } \\
\text { lactucae Kalt., } \\
\text { specimens/bus } \\
\text { h }\end{array}$ & $\begin{array}{c}\text { s } \\
\text { urticae } \\
\text { Koch, } \\
\text { specimens/ } \\
\text { leaf }\end{array}$ & $\begin{array}{l}\text { Cecidophyopsis } \\
\text { ribis Westw, } \\
\text { buds/branch }\end{array}$ & $\begin{array}{l}\text { Gioesporium } \\
\text { ribis Mont. }\end{array}$ & $\begin{array}{l}\text { Sphaerothec } \\
\text { a } \\
\text { mors Uvae. }\end{array}$ & $\begin{array}{l}\text { Mycosphaerella } \\
\text { ribis Lind. }\end{array}$ \\
\hline 1 & very low & 5 & 11 & 2 & 15 & 2 & 4 \\
\hline $2-3$ & low & 10 & 20 & 5 & 18 & 6 & 7 \\
\hline $4-5$ & medium & 30 & 45 & 12 & 29 & 8 & 11 \\
\hline $6-7$ & high & 80 & 60 & 20 & 32 & 11 & 13 \\
\hline $8-9$ & very high & 160 & 75 & 29 & 48 & 16 & 15 \\
\hline
\end{tabular}

A number of sucking phytophagous insects were found in black currant plantations. Pests were calculated and it has been found that depending on the weediness level, the number of Hyperomyzus lactucae Kalt. ranged from 5 to 160 specimens per bush, Tetranychus urticae Koch - 11-75 specimens/leaf, Cecidophyopsis ribis Westw. - 2-29 buds per branch.

Fungal diseases have become widespread in currant plantations. The dominant disease was Gioesporium ribis Mont. It has been found that under a high and very high weediness level (8-9 points) the affection with this disease was $32-48 \%$, which is by $17-33 \%$ higher than under a very low weediness level (1 point). The affection with Sphaerotheca mors Uvae. and Mycosphaerella ribis Lind. Was much lower. Under the weediness level at 8-9 points, the affection with diseases in currant plantations was at the level of 16 and $15 \%$, respectively, which is by 14 and $11 \%$ more than under a very low weediness (point 1 ).

The most important factors for further stabilization and increase of black currant yield capacity are the implementation of intensive cultivation technologies with innovative methods and means of protection against pests, diseases and weeds. Particular attention is paid to the development of fundamentally new methods and tools for identification, control and prediction of the most dangerous harmful species that can cause the maximum level of harm and to the improvement of the existing ones. The ever-increasing requirements for environmental safety are an important stimulus for research and development aimed at regulating the number of weeds in black currant plantations.

Decreased resistance of currant to pests and diseases negatively affected the yield and quality of berries (Table 4).

Table 4. Influence of the weediness level of black currant plantations on the structure and yield of berries, 2017-2019.

\begin{tabular}{|c|c|c|c|c|c|c|c|}
\hline \multicolumn{2}{|c|}{ Weediness } & \multicolumn{3}{|c|}{ Weight } & \multicolumn{3}{|c|}{ Yielding capacity of berries, $t$} \\
\hline points & weediness level & $\begin{array}{c}\text { an average } \\
\text { berry, } g\end{array}$ & $\begin{array}{c}100 \\
\text { berries, } \mathrm{g}\end{array}$ & $\begin{array}{c}\text { berries } \\
\text { from a } \\
\text { bush, kg }\end{array}$ & average & \pm to control & $\%$ \\
\hline $2-3$ & low & 2.2 & 256 & 1.755 & 7.8 & -0.7 & 92 \\
\hline $4-5$ & medium & 1.9 & 243 & 1.462 & 6.5 & -2.0 & 76 \\
\hline $6-7$ & high & 1.1 & 201 & 1.283 & 5.7 & -2.8 & 67 \\
\hline
\end{tabular}

It has been found that the weediness level in black currant plantations directly affects the structure and yield of berries. Thus, under low and medium weediness level (2-3 and 4-5 points) the weight of an average berry decreases from 2.6 to $0.8 \mathrm{~g}$; on average the weight decreases from 2.2 to $1.9 \mathrm{~g}$. One hundred berries also weigh less; under a very strong weediness level (8-9 points), the 100 berries weighed by $85 \mathrm{~g}$ less compared to a very weak weediness level (1 point). Under low weediness level, deviations are insignificant. However, if one takes into account the weight of berries from a bush, the figure is significantly lower, by $157 \mathrm{~g}$. Under the highest weediness level, the weight of berries from a bush decreases from 1.912 to $1.080 \mathrm{~kg}$, i.e., the lack of harvest rapidly reduces the weight of berries by $832 \mathrm{~g}$, and has a direct negative impact on the potential yield capacity of black currant. Over the years of the study, the average yield under different weediness levels decreases from 8.5 to $4.8 \mathrm{t}$ /ha, while the increase in yield under a very high weediness level (8-9 points) decreases by $3.7 \mathrm{t} / \mathrm{ha}$. Thus, the effect of different weediness levels on black currant plantations reduces the yield of berries by $56 \%$ and creates conditions for the reservation of sucking phytophagous insects, the number of which increases tenfold, which negatively affects the growth and development of plants.

\section{Discussion}

It should be pointed out that weeds not only significantly reduce the yield and quality of berries, but also contribute to the reproduction of pests and pathogens and increase the cost of plant care (Solomahin et al., 2008). Weeds reduce plant growth and productivity in currant agrocoenoses; this is a result of competition for moisture, minerals, shading, etc. (Rohrig et al., 2019; Kendir et al., 2019). Some scientists believe that high weediness of berry crops, especially in the first years after planting, weakens growth and development of plants, and in some cases causes their death (Yang et al., 2019).

When measures aimed at limiting the number of weeds in black currant agrophytocoenosis are planned, it is necessary to take into account the main ecological and biological features of development and spreading of weeds, their species composition, technique and technological properties for the application of preparations in a particular region (Yang et al., 2019). Many years of experience of scientists have shown that each berry crop in a particular soil and climatic zone has a specific weed coenosis (Sinkevich \& Misyuk, 
2015). Species and quantitative composition of weeds changes over time depending on the influence of climatic factors and agricultural technologies (Morozov et al., 2018). According to many scientists, the main method of weed control is the use of highly toxic herbicides, which has a negative impact on the environment, reduces the beneficial microflora and affects human health (Tian et al., 2019). Black currant berries are an excellent sorbent during ripening; and this requires great care when choosing preparations, time and methods of their use (Lee \& Lee, 2019). It is impossible to provide recommendations for the use of herbicides in berry growing without knowledge of their residual amount in berries (Veselovskyi et al., 1988). The specific aspects of the use of herbicides in berry agrocoenoses are related to the species composition of weeds and their adaptation to the technology of cultivation (Fisyunov, 1984). When herbicides are used to kill weeds, favorable conditions are created for the cultivation of berry crops; they effectively use moisture and nutrients from the soil (Selvaraj et al., 2019; Aliev, 2010). According to some scientists, under the influence of herbicides on weeds under certain conditions, due to the nature of the preparation, biological characteristics of the crop, soil and climatic conditions, as well as the interaction of various factors (Zurn et al., 2019).

\section{Conclusion}

The study of the weediness level in black currant plantations identified 12 species of weeds, among them 8 annual species ( $89.8 \%$ ) and 4 perennial ones (10.2\%). Dominant annual weeds were Chenopodium album L., Capsella bursa-pastoris L., Poa annua L., Amaranthus retroflexus L., Stellaria media L., Urtica urens L., Galinsoga parviflora Cav., Viola arvensis; while among perennial these were Taraxacum officinale Wigg., Sonchus arvensis L., Elytrigia repens L., and Rumex acetostella L.

It has been found that the weediness level of black currant plantations significantly affects the growth and development of plants. Depending on the weediness level, the weight of black currant leaves from a bush decreased by $0.7 \mathrm{~kg}$, the area of currant leaves from a bush by $1.9 \mathrm{~m}^{2}$, the chlorophyll content in the leaves by $20.8 \mathrm{mg} / 100 \mathrm{~g}$ compared to a very low weediness level at 1 point. The dry matter content in currant leaves was $29-61 \%$ and, on the contrary, increased by $32 \%$ under a very high weediness level.

Under a high (6-7 points) and very high (8-9 points) weediness level of black currant, an intensive infestation with sucking phytophagous insects (Hyperomyzus lactucae Kalt., Tetranychus urticae Koch, Cecidophyopsis ribis Westw.) was detected. In addition, the affection with fungal diseases increased (Gioesporium ribis Mont., Sphaerotheca mors Uvae., Mycosphaerella ribis Lind.)

Decreased resistance of currant to pests and diseases negatively affected the formation of the yield and the quality of berries. Under a very high weediness level, the yield decreased by $3.7 \mathrm{t} /$ ha compared to low weediness, and losses amounted to $56 \%$ of the total berry harvest.

\section{References}

Aliev, T. G. (2010). Tehnologiya po borbe s sornyakami v nasazhdeniyah plodovyih i yagodnyih kultur Tsentralno-Chernozemnoy Zonyi Rossii. Problemyi razvitiya APK regiona, 3(3), 57-68. (in Russian).

Aliev, T. G., Krivoschekov, L. I. \& Titova, E. G. (2018). Monitoring sornoy rastitelnosti v plodovyih i yagodnyih nasazhdeniyah TsChZ. Pochvyi i ih effektivnoe ispolzovanie. Materialyi Mezhdunarodnoy nauchno-prakticheskoy konferentsii, posvyaschennoy 90-letiyu so dnya rozhdeniya d. s.-h. n., zasluzhennogo deyatelya nauki Rossiyskoy Federatsii,professora Vladimira Vladimirovicha Tyulina. (in Russian).

Bakalova, A., Tkalenko, H., Hrytsiuk, N., Krukodera, Y. \& Herasymchuk, D. (2020). Effectiveness of combined application of insecticides and complex fertilizers in the protection of black fragrance from summer pest in Ukraine. Quarantine and plant protection, 1, 5-8. DOI:https://doi.org/10.36495/2312-0614.2020.01.5-8. (in Ukrainian).

Dobrucka, R., Dlugaszewska, J. \& Kaczmarek, M. (2016). Antimicrobial and cytostatic activity of biosynthesized nanogold prepared using fruit extract of Ribes nigrum. Arabian journal of chemistry, 12(8), 3902-3910. DOI: 10.1016/j.arabjc.2016.02.009.

Fisyunov, A. V. (1984). Sornyie rasteniya. Moskva : Kolos. (in Russian).

Kendir, G., Suntar, I., Ceribasi, A. O. \& Koroglu, A. (2019). Activity evaluation on Ribes species, traditionally used to speed up healing of wounds: With special focus on Ribes nigrum. Journal of ethnopharmacology, 237, 141-148. DOI: 10.1016/j.jep.2019.03.038.

Kjaer, K. H., Winde, J., Petersen, K. K., Yde, C. C. \& Pagter, M. (2019). Cold deacclimation mechanisms and reacclimation potential in flower buds of blackcurrant (Ribes nigrum). Physiologia plantarum, 167(1), 111-126. DOI: 10.1111/ppl.12873.

Lee, Y. \& Lee, J. Y. (2019). Blackcurrant (Ribes nigrum) Extract Exerts an Anti-Inflammatory Action by Modulating Macrophage Phenotypes. Nutrients, 11(5), 5821-5833. DOI: 10.3390/nu11050975.

Maltceva, A. I. (1936). Sornaia rastitelnost SSSR i mery borby s nei. Moskva-Leningrad : Selkhozgid, 1936. (in Russian).

Marsol-Vall, A., Laaksonen, O. \& Yang, BR. (2019). Effects of processing and storage conditions on volatile composition and odor characteristics of blackcurrant (Ribes nigrum) juices. Food chemistry,93, 151-160. DOI: 10.1016/j.foodchem.2019.04.076.

Morozov, V. I., Toygildin, A. L. \& Podsevalov, M. I. (2018). Floristicheskiy sostav i dinamika chislennosti sornyih rasteniy agrofitotsenozov v sevooborotah lesostepnoy zonyi Povolzhya. Vestnik Ulyanovskoy gosudarstvennoy selskohozyaystvennoy akademii, 4 (44), 102-109. (in Russian).

Postolenko, L. V. (2016). Biolohichni osoblyvosti rozvytku smorodyny chornoi zalezhno vid vplyvu mulchuvannia gruntu. Visnyk Natsionalnoho universytetu vodnoho hospodarstva ta pryrodokorystuvannia. Silskohospodarski nauky, 3, 121-129. (in Ukrainian).

Rantala, S., Kaseva, J., Karhu, S., Vetelainen, M., Uosukainen, M. \& Haggman, H. (2019). Cryopreservation of Ribes nigrum (L.) dormant buds: recovery via in vitro culture to the field. Plant cell tissue and organ culture, 138(1), 109-119. DOI: 10.1007/s11240019-01607-5.

Rutkovskaya, L. S. \& Misyuk, E. M. Zaschita matochnyih nasazhdeniy smorodinyi chernoy ot sornoy rastitelnosti. Plodovodstvo i yagodovodstvo Rossii, 49, 278-281. (in Russian).

Rohrig, T., Kirsch, V., Schipp, D., Galan, J. \& Richling, E. (2019). Absorption of Anthocyanin Rutinosides after Consumption of a Blackcurrant (Ribes nigrum L.) Extract. Journal of agricultural and food chemistry, 67(24), 6792-6797. DOI: 10.1021/acs.jafc.9b01567. Sinkevich, I. A. \& Misyuk, E. M. (2015). Vidovoy sostav sornoy rastitelnosti v nasazhdeniyah smorodinyi chernoy. Sovremennyie tehnologii selskohozyaystvennogo proizvodstva : sb. nauch. stat. po materialam HVIII Mezhdunarodnoy nauchno-prakticheskoy konferentsii. Grodno : GGAU. (in Russian).

Selvaraj, K., Katare, D. P., Kumar, P. \& Chaudhary, N. (2019). Juglans regia and Ribes nigrum as potential nutraceuticals: Source of thermostable superoxide dismutase enzyme. Journal of food biochemistry, 43(5), 5441-5453. DOI: 10.1111/jfbc.12823.

Solomahin, A. A., Aliev, T. G. \& Arhipov, Yu. A. (2008). Borba s sornoy rastitelnostyu na yagodnyih kulturah. Zaschita i karantin rasteniy, 6, 26-27. (in Russian). 
Tian, Y., Laaksonen, O., Haikonen, H., Vanag, A., Ejaz, H., Linderborg, K., Karhu, S. \& Yang, B. R. (2019). Compositional Diversity among Blackcurrant (Ribes nigrum) Cultivars Originating from European Countries. Journal of Agricultural and Food Chemistry, 67(19), 5621-5633. DOI: 10.1021/acs.jafc.9b00033.

Veselovskyi, I. V., Lysenko, A. K. \& Manko Yu. P. (1988). Atlas-vyznachnyk burianiv. Kyiv : Urozhai. (in Ukrainian).

Yang, W., Kortesniemi, M., Ma, X. Y., Zheng, J. \& Yang, B. R. (2019). Enzymatic acylation of blackcurrant (Ribes nigrum) anthocyanins and evaluation of lipophilic properties and antioxidant capacity of derivatives. Food Chemistry, 281, 189-196. DOI: $10.1016 /$ j.foodchem.2018.12.111.

Zurn, J. D., Ho, T., Li, R., Bassil, N. V., Tzanetakis, I. E., Martin, R. R. \& Postman, J. D. (2019). First report of blackcurrant reversion virus in Ribes nigrum germplasm in the United States. Plant disease, 103(5), 1051-1052. DOI: 10.1094/PDIS-03-18-0526-PDN.

\section{Citation:}

Bakalova, A.V., Hrytsiuk, N.V., Tkalenko, N.M., Stoliar, S.H. (2020). Special aspects of the development of black currant bushes depending on weediness level in the Ukrainian Polissia. Ukrainian Journal of Ecology, 10(4), 18-22. 